\title{
Impact of Pulmonary Exposure to Cerium Oxide Nanoparticles on Experimental Acute Kidney Injury
}

\author{
Abderrahim Nemmara Suhail Al-Salam ${ }^{b} \quad$ Zinab Al Ansaria ${ }^{a}$ Zainab A. Alkharas ${ }^{a}$ \\ Rauda M. Al Ahbabia Sumaya Beegama Priya Yuvarajua Javed Yasin ${ }^{\mathrm{c}}$ \\ Badreldin H. Ali ${ }^{d}$ \\ aDepartment of Physiology, College of Medicine and Health Sciences, United Arab Emirates University, \\ Al Ain, United Arab Emirates, 'Department of Pathology, College of Medicine and Health Sciences, \\ United Arab Emirates University, Al Ain, United Arab Emirates, 'Department of Internal Medicine, \\ College of Medicine and Health Sciences, United Arab Emirates University, Al Ain, United Arab \\ Emirates, dDepartment of Pharmacology, College of Medicine \& Health Sciences, Sultan Qaboos \\ University, Al-Khod, Sultanate of Oman
}

\section{Key Words}

Cerium oxide nanoparticles $\cdot$ Lung inflammation - Acute renal failure

\begin{abstract}
Background/Aims: Cerium oxide nanoparticles $\left(\mathrm{CeO}_{2} \mathrm{NPs}\right)$ are released from diesel engines that use cerium compounds as a catalytic agent to decrease the diesel exhaust particles, leading to human exposure by inhalation to $\mathrm{CeO}_{2} \mathrm{NPs}$. We have recently demonstrated that pulmonary exposure to $\mathrm{CeO}_{2} \mathrm{NPs}$ induces lung inflammation, thrombosis, and oxidative stress in various organs including kidneys. It is well known that particulate air pollution effects are greater in patients with renal diseases. The aim of this study is to investigate the effects of pulmonary exposure to $\mathrm{CeO}_{2} \mathrm{NPs}$ in a rat model of acute kidney injury (AKI). Methods: AKI was induced in rats by a single intraperitoneal injection of cisplatin $(C P, 6 \mathrm{mg} / \mathrm{kg})$. Six days later, the rats were intratracheally (i.t.) instilled with either $\mathrm{CeO}_{2} \mathrm{NPs}(1 \mathrm{mg} / \mathrm{kg})$ or saline (control), and various renal and pulmonary endpoints were assessed $24 \mathrm{~h}$ afterward using histological, colorimetric assay, enzyme-linked immunosorbent assay and Comet assay techniques. Results: CP alone decreased body weight, and increased water intake, urine volume and relative kidney weight. $\mathrm{CP}$ also increased the plasma concentrations urea and creatinine, and decreased creatinine clearance. In the kidneys, CP significantly increased renal injury molecule-1, interleukin-6 (IL-6), tumor necrosis factor $\alpha$ (TNF $\alpha$ ) and glutathione concentrations, and caused renal tubular necrosis, and DNA injury assessed by Comet assay. All these actions were significantly aggravated in rats given both $\mathrm{CP}$ and $\mathrm{CeO}_{2} \mathrm{NPs}$. Histopathological changes in lungs of $\mathrm{CeO}_{2} \mathrm{NPs}$-treated rats included marked interstitial cell infiltration and congestion.
\end{abstract}




\section{Cellular Physiology Cell Physiol Biochem 2019;52:439-454 \\ \begin{tabular}{ll|l} 
and Biochemistry $\begin{array}{l}\text { DOl: 10.33594/000000032 } \\
\text { Published online: } 15 \text { March 2019 }\end{array}$ & $\begin{array}{l}\text { O } 2019 \text { The Author(s). Published by } \\
\text { Cell Physiol Biochem Press GmbH\&Co. KG }\end{array}$ \\
\cline { 2 - 3 } &
\end{tabular} \\ Nemmar et al.: Cerium Oxide Nanoparticles and Acute Kidney Injury}

These were aggravated by the combination of $\mathrm{CP}+\mathrm{CeO}_{2} \mathrm{NPs}$. Moreover, this combination exacerbated the increase in the concentrations of TNF $\alpha$ and IL-6, and the decrease in the activity of pulmonary catalase and total nitric oxide concentration, and lung DNA damage. Conclusion: We conclude that the presence of $\mathrm{CeO}_{2} \mathrm{NPs}$ in the lung exacerbated the renal and lung effects of CP-induced AKI.

(C) 2019 The Author(s). Published by

Cell Physiol Biochem Press GmbH\&Co. KG

\section{Introduction}

There has been an accelerated increase in the use of different types of nanomaterials as a result of their unique physicochemical and bioreactive characteristics. Nanomaterials possess different physicochemical and biological properties than larger materials of identical chemical composition. They are used in industries including sunscreens, food, paints, textile, electronics, sports, and biomedical application and imaging [1]. Nonetheless, extensive use of nanomaterials may lead to exposure of humans by various routes including inhalation, dermal and oral routes, raising concerns about their potential toxicity $[1,2]$.

Cerium oxide nanoparticles $\left(\mathrm{CeO}_{2} \mathrm{NPs}\right)$ have been used in Europe, Asia and North America as fuel additive, which serves as a combustion catalyst leading to enhanced fuel efficiency [3-6]. Although this addition enhances the ability of diesel engines and reduces the emission of diesel exhaust particles (DEP), it leads, however, to direct emission of $\mathrm{CeO}_{2}$ NPs in the environment leading to human exposure by inhalation [7]. The latter could have adverse health effects [7].

It has been shown that exposure to $\mathrm{CeO}_{2} \mathrm{NPs}$ causes inflammation and oxidative stress leading to apoptosis and autophagy in vitro [8] and lung inflammation and fibrosis after their pulmonary exposure in vivo $[9,10]$. Furthermore, it has been demonstrated that following their pulmonary deposition, $\mathrm{CeO}_{2} \mathrm{NPs}$ are able to pass through the air-blood barrier and reach the systemic circulation, and from there distribute to various sites in the body [11]. We have recently demonstrated that pulmonary exposure to $\mathrm{CeO}_{2} \mathrm{NPs}$ induces lung inflammation and thrombotic events, and cause inflammation and oxidative stress in various extrapulmonary sites, including the kidneys $[12,13]$.

It is well-established that there is a crosstalk between the lung and the kidney, and that their functions are tightly associated under physiological and pathophysiological situations [14]. In fact, it is well-known that different diseases that may affect one organ can have direct consequences on the other one [14]. It has been shown that lung injury can worsen kidney failure [14]. Moreover, it has been reported that patients with pre-existing diseases such as kidney failure are more susceptible to the adverse health effect of particulate air pollution [15]. Actually, it has been demonstrated that living near a major roadway contributes to the decline in renal function [16]. We have also recently provided experimental evidence that pulmonary exposure to diesel exhaust particles (DEPs) aggravate both acute and chronic renal failure $[17,18]$. However, as far as we are aware, little is known about the impact of lung exposure to $\mathrm{CeO}_{2} \mathrm{NPs}$ in animal model of acute renal failure. As far as we know, only one study has reported that $\mathrm{CeO} 2 \mathrm{NPs}$ attenuate acute kidney injury induced by intra-abdominal infection in Sprague-Dawley rats [19]. The latter findings are in complete disagreement with various publications reporting that $\mathrm{CeO} 2 \mathrm{NPs}$ induce inflammation, oxidative stress and DNA damage in various organs including the kidneys [8-10, 12,13].

Consequently, the purpose of this study was to evaluate whether and to what extent pulmonary exposure to $\mathrm{CeO} 2$ NPs may have an exacerbating effects in an animal model of acute kidney injury (AKI) induced by cisplatin (CP, [cis-diaminedichloroplatinum II]), an anticancer drug, which induces nephrotoxicity through inflammation, apoptosis and generation of reactive oxygen species [20], by assessing various renal and pulmonary variables. 


\section{\begin{tabular}{ll} 
Cellular Physiology & Cell Physiol Biochem 2019;52:439-454 \\
\hline DOl: 10.33594/000000032 & 2019 The Author(s). Published by
\end{tabular} and Biochemistry Published online: 15 March $2019 \quad \begin{aligned} & \text { Ce } 2019 \text { The Author(s). Published by } \\ & \text { Cell Physiol Biochem Press GmbH\&Co. KG }\end{aligned}$}

\section{Materials and Methods}

\section{Particles}

$\mathrm{CeO}_{2}$ NPs, $10 \mathrm{wt} \%$ in water with average diameter at $\sim 20 \mathrm{~nm}$, were obtained from Sigma-Aldrich (St Louis, MO, USA). $\mathrm{CeO}_{2}$ NPs samples diluted in saline were used for rat exposures. To minimize aggregation, particle suspensions were always sonicated for 5 min (Clifton Ultrasonic Bath, Clifton, New Jersey, USA). Particle suspensions were prepared promptly before use and were vortexed to offer well mixed suspension prior each instillation. The same particles from the same source were characterized and used recently by Ma and co-workers $[10,21]$.

The endotoxin concentration in the $\mathrm{CeO}_{2}$ NPs and saline used was quantified, as described by the manufacturer, by chromogenic Limulus Amebocyte Lysate (Pierce, Rockford, IL) test. The concentrations were lower than the detection limit $(0.1 \mathrm{EU} / \mathrm{ml})$ in the saline, and $\mathrm{CeO} 2 \mathrm{NPs}$ solutions.

\section{Animals and i.t. instillation}

This project was reviewed and approved (ERA_2016_4408) by the Institutional Review Board of the United Arab Emirates University, College of Medicine and Health Sciences, and experiments were performed in accordance with protocols approved by the Institutional Animal Care and Research Advisory Committee.

Male Wistar rats (Taconic Farms Inc., Germantown, New York, USA), aged 10-12 weeks and initially weighing $223 \pm 13 \mathrm{~g}$, were given a standard laboratory chow and water ad libitum. They were randomly divided into four groups and individually housed in metabolic cages, to facilitate urine collection, at a temperature of $23 \pm 2^{\circ} \mathrm{C}$, relative humidity of 50-60\% and a 12-h dark-light cycle. An acclimatization period of four days was allowed for the rats before any experimentation. The rats were weighed at the beginning of the experiment and just before sacrifice. Rats were cared for under a protocol approved by the Animal Research Ethics Committee of our college, and according to the NIH Guide for the Care and Use of Laboratory Animals, NIH publication no. 85-23, 1985.

\section{Treatments}

The AKI in rats was induced by a single intraperitoneal (i.p.) injection of CP (David Bull Laboratories, PTY Ltd, Victoria, Australia) at a dose of $6 \mathrm{mg} / \mathrm{kg}[22,23]$. Control animals received similar volume of normal saline i.p. On day 6 of treatment, the animals were anesthetized by isoflurane inhalation, and placed supine with extended neck on an angled board. A Becton Dickinson 18 Gauge cannula was inserted via the mouth into the trachea. CeO2 NPs suspension $(150 \mu \mathrm{l})$ or saline-only were instilled $(150 \mu \mathrm{l})$ via a sterile syringe and followed by an air bolus of $100 \mu \mathrm{l}$.

The four groups were treated as follows:

Group 1: single normal saline (control, $500 \mu \mathrm{l} / \mathrm{rat}$ ) given i.p., and on day 6 of the treatment, a single i.t. administration of saline ( $150 \mu \mathrm{l}$ per rat);

Group 2: single normal saline (control, $500 \mu \mathrm{l} / \mathrm{rat}$ ) given i.p., and on day 6 of the treatment, a single i.t. administration of $\mathrm{CeO}_{2} \mathrm{NPs}(1 \mathrm{mg} / \mathrm{kg})$;

Group 3: single CP ( $6 \mathrm{mg} / \mathrm{kg})$ given i.p., and on day 6 of the treatment, a single i.t. administration of saline $(150 \mu$ l per rat);

Group 4: single CP (6 mg/kg) given i.p., and on day 6 of the treatment, a single i.t. administration of $\mathrm{CeO}_{2}$ NPs $(1 \mathrm{mg} / \mathrm{kg})$;

On day 6, immediately after i.t. administration of saline or $\mathrm{CeO}_{2} \mathrm{NPs}$, rats were placed in metabolic cages, and urine of each rat was collected over a 24 -h period and the volume measured.

\section{Blood collection, histology and biochemical analysis}

Rats were anesthetized with sodium pentobarbital $(60 \mathrm{mg} / \mathrm{kg}$, i.p.), and blood was drawn from the inferior vena cava in ethylenediaminetetraacetic acid (4\%). The collected blood was centrifuged at $4^{\circ} \mathrm{C}$ for $15 \mathrm{~min}$ at $900 \times \mathrm{g}$, and the plasma samples were stored at $-80^{\circ} \mathrm{C}$ pending analysis.

The animals were sacrificed with an overdose of anesthesia. Right kidneys were excised, washed with ice-cold saline, blotted with filter paper and weighed. Each kidney was cassetted and fixed directly in $10 \%$ neutral formalin for 24 hours, which was followed by dehydration in increasing concentrations of ethanol, clearing with xylene and embedding with paraffin. Four- $\mu \mathrm{m}$ sections were prepared from paraffin blocks and stained with hematoxylin and eosin. The stained sections were evaluated by the histopathologist (S.A.), 


\section{Cellular Physiology Cell Physiol Biochem 2019;52:439-454 \\ \begin{tabular}{ll|l} 
and Biochemistry & $\begin{array}{l}\text { DOl: 10.33594/000000032 } \\
\text { Published online: } 15 \text { March 2019 }\end{array}$ & $\begin{array}{l}\text { O } 2019 \text { The Author(s). Published by } \\
\text { Cell Physiol Biochem Press GmbH\&Co. KG }\end{array}$ \\
\cline { 2 - 3 } &
\end{tabular} \\ Nemmar et al.: Cerium Oxide Nanoparticles and Acute Kidney Injury}

using light microscopy. The microscopic scoring of the kidney sections was carried out in a blinded fashion by our histopathologist who was unaware of the treatment groups and assigned a score which represents measurement of extent of acute tubular injury area in the cortical and medullary tubules on a scale of 0-4 $(0$, no acute tubular injury; 1 , a few focal acute tubular injury areas of $\leq 25 \%$ of the kidney; 2 , acute tubular injury area was about $26-50 \%$ of kidney; 3 , acute tubular injury area was $51-75 \%$ of kidney; 4 , showing acute tubular injury in $76-100 \%$ of kidney) [24]. Image J software (NIH, USA) was used to measure the extent of necrosis.

Right lungs were excised, washed with ice-cold saline, blotted with filter paper and weighed. Then they were fixed by with $10 \%$ buffered formalin. Each lung was sectioned, casseted and dehydrated in increasing concentrations of ethanol, cleared with xylene and embedded with paraffin. Three- $\mu$ m sections were prepared from paraffin blocks and stained with haematoxylin and eosin. The stained sections were evaluated using light microscopy.

The concentrations of urea in plasma, and creatinine in both plasma and urine were spectrophotometrically measured using commercial kits (Roche Diagnostics, Indianapolis, IN, USA).

Left kidneys and left lungs of rats from the different groups were quickly collected and rinsed with icecold PBS (pH 7.4) before homogenization, as described before $[13,25]$. The homogenates were centrifuged for $10 \mathrm{~min}$ at $3000 \mathrm{xg}$ to remove cellular debris, and the supernatants were used for further analysis [25]. Protein content was measured by Bradford's method. The concentrations of tumor necrosis factor $\alpha$ (TNF $\alpha$ ) (Duo Set, R \& D systems, Minneapolis, MN, USA), interleukin 6 (IL-6) (Duo Set, R \& D systems, Minneapolis, MN, USA), kidney injury molecule 1 (KIM) (Duo Set, R \& D systems, Minneapolis, MN, USA) and glutathione (GSH) (Sigma-Aldrich Fine Chemicals, St Louis, MO, USA) were determined in kidney homogenates using commercial Kits.

In lung homogenates, IL- 6 and $\mathrm{TNF} \alpha$, as well as catalase activity were measured using a kit from Cayman Chemicals Company (Ann Arbor, MI, USA) and the determination of NO was performed with a total NO assay kit from R \& D systems (Minneapolis, MN, USA) which measures the more stable NO metabolites $\mathrm{NO}_{2}^{-}$and $\mathrm{NO}_{3}^{-}[26,27]$.

\section{Assessment of DNA damage by COMET assay}

Immediately after sacrifice, the lung and kidneys were removed from each animal. Single-cell suspensions of the different lungs and kidneys were obtained and analyzed according to the method described in our previous publications [28-31]. Each collected organ was washed in a chilled medium (RPMI $1640,15 \%$ DMSO, 1.8\% (w/v) NaCl). The lung and kidney tissues were put in $1.5 \mathrm{ml}$ medium and cut finely into pieces in a Petri dish. The slices were allowed to deposit and the supernatant was collected in a $15 \mathrm{ml}$ tube. The collected cell suspension was centrifuged at $1000 \mathrm{rpm}$ for $5 \mathrm{~min}$ at $4^{\circ} \mathrm{C}$. The supernatant was removed and the pellets were suspended in $0.5 \mathrm{ml}$ of the medium. The cell suspensions were mixed with low melting point agarose solution (0.65\%) and spread onto agarose (1.5\%)-precoated microscope slides. For each group, five slides were prepared and incubated in ice cold lysis buffer $(2.5 \mathrm{M} \mathrm{NaCl}, 10 \mathrm{mM}$ Tris, $100 \mathrm{mM}$ EDTA, $1 \%$ Triton X-100 and $10 \%$ DMSO) at $4^{\circ} \mathrm{C}$ for at least one hour to remove the cell membranes. Following incubation, slides were placed in a horizontal electrophoresis unit and incubated in electrophoresis buffer (0.2M EDTA, 5M NaCl, pH 10) for 20 min for DNA unwinding and the expression of alkali labile sites. Then, electrophoresis was conducted for $20 \mathrm{~min}$ at $25 \mathrm{~V}$ and $300 \mathrm{~mA}$. After that, the slides were neutralized with Tris buffer (0.4M Trizma base, pH 7.5) for 5 min and washed with methanol. Then the slides were stained with propidium iodide, as previously described $[29,32]$. All these steps were performed in darkness to prevent additional DNA damage. The slides were mounted on a fluorescent microscope and cell scoring was performed. The measurement of length of the DNA migration (i.e. diameter of the nucleus plus migrated DNA) was calculated using the image analysis Axiovision 3.1 software (Carl Zeiss, Canada) [29, 33].

\section{Statistics}

All data were analyzed with GraphPad Prism Version 4.01 for Windows software (Graphpad Software Inc., San Diego, USA). Data were analyzed for normal distribution using using the D'Agostino and Pearson omnibus normality test. Data are expressed as means \pm SEM. Comparisons between groups were performed by one way analysis of variance (ANOVA), followed by Newman Keuls test for comparing treated with control data. $P$ values $\leq 0.05$ are considered significant. 


\section{Cellular Physiology Cell Physiol Biochem 2019;52:439-454 \begin{tabular}{ll|l} 
and Bol: 10.33594/000000032 & $\begin{array}{l}\text { O } 2019 \text { The Author(s). Published by } \\
\text { Cell Physiol Biochem Press GmbH\&Co. KG }\end{array}$ \\
\cline { 2 - 3 }
\end{tabular}}

\section{Results}

Body weight, relative kidney weight, water intake and urine volume

Fig. $1 \mathrm{~A}$ displays no difference in body weight between saline and $\mathrm{CeO}_{2} \mathrm{NPs}$ groups. Nevertheless, rats treated concomitantly with $\mathrm{CP}$ and saline lost about $17.2 \%(\mathrm{P}<0.001$ versus saline group), while those administered with $\mathrm{CP}$ and $\mathrm{CeO}_{2}$ NPs lost about $20.5 \%$ $(\mathrm{P}<0.001$ versus DEP group), respectively. Fig. 1B shows that the relative kidney weight was significantly augmented in rats given $\mathrm{CP}+$ saline compared with those administered with saline only $(\mathrm{P}<0.01)$. Moreover, the relative kidney weight was significantly increased in rats administered with $\mathrm{CP}+\mathrm{CeO}_{2}$ NPs compared with those given either $\mathrm{CeO}_{2} \mathrm{NPs}$ only $(\mathrm{P}<0.001)$ or those given saline $+C P(P<0.001)$. Fig. $1 \mathrm{C}$ shows that water intake was significantly increased in the $\mathrm{CP}+$ saline group compared with the saline alone $(\mathrm{P}<0.05)$, and the $\mathrm{CP}+\mathrm{CeO}_{2}$ NPs group compared with either $\mathrm{CP}+$ saline group $(\mathrm{P}<0.05)$ or $\mathrm{CeO}_{2} \mathrm{NPs}$ alone $(\mathrm{P}<0.001)$. Similarly, Fig. 1D shows that urine volume was significantly augmented in the $\mathrm{CP}+$ saline group compared with the saline group $(\mathrm{P}<0.001)$, and the $\mathrm{CP}+\mathrm{CeO}_{2} \mathrm{NPs}$ group compared with either $\mathrm{CP}+$ saline group $(\mathrm{P}<0.01)$ or $\mathrm{CeO}_{2} \mathrm{NPs}$ group $(\mathrm{P}<0.001)$.

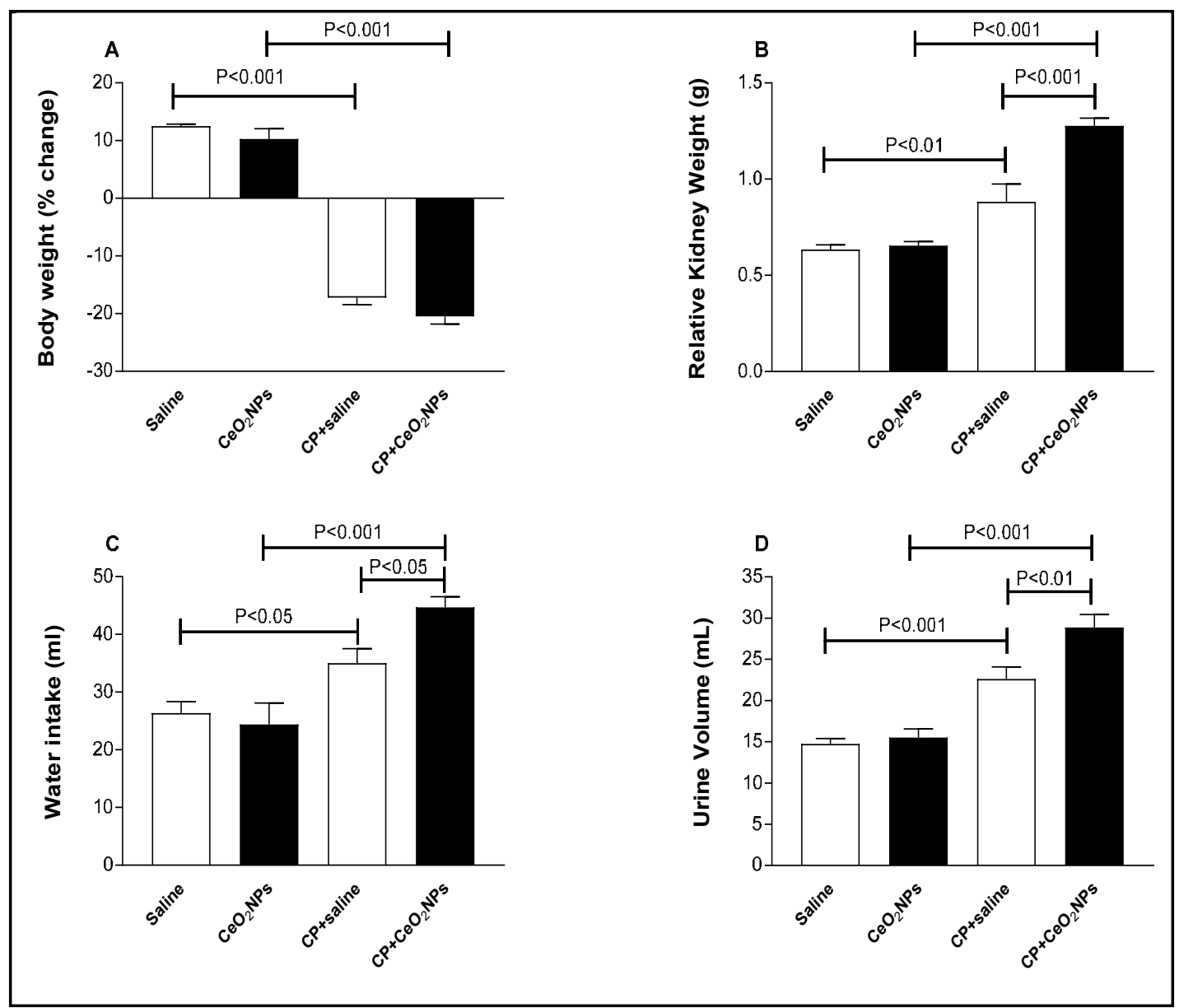

Fig. 1. Body weight $(A)$, relative kidney weight $(B)$, water intake (C) and urine volume (D) in Wistar rats intratracheally instilled with either saline (control) or cerium oxide nanoparticles $\left(\mathrm{CeO}_{2} \mathrm{NPs}\right)$ with or without cisplatin (CP) administration. Data are mean \pm SEM. Body and kidney weights: saline $(n=8), \mathrm{CeO}_{2}$ NPs (n=8), CP+saline (n=8) and $\mathrm{CP}+\mathrm{CeO}_{2} \mathrm{NPs}(\mathrm{n}=8)$. Water intake: saline (n=6), $\mathrm{CeO}_{2} \mathrm{NPs}(\mathrm{n}=8), \mathrm{CP}+$ saline $(\mathrm{n}=8)$ and $\mathrm{CP}+\mathrm{CeO}_{2} \mathrm{NPs}(\mathrm{n}=6)$. Urine volume: saline $(\mathrm{n}=8), \mathrm{CeO}_{2} \mathrm{NPs}(\mathrm{n}=8), \mathrm{CP}+$ saline $(\mathrm{n}=8)$ and $\mathrm{CP}+\mathrm{CeO}_{2}$ NPs $(n=7)$. 
Plasma creatinine and urea concentration and creatinine clearance

Fig. 2A shows no difference in urea concentration has been observed between saline and $\mathrm{CeO}_{2}$ NPs groups. However, rats treated with $\mathrm{CP}+$ saline showed a significant increase in the concentration of urea compared with the saline group $(\mathrm{P}<0.001)$. Remarkably, $\mathrm{CP}+\mathrm{CeO}_{2} \mathrm{NPs}$ treatment significantly augmented the concentration of urea more than in rats given either $\mathrm{CP}+$ saline $(\mathrm{P}<0.05)$ or $\mathrm{CeO}_{2}$ NPs alone $(\mathrm{P}<0.001)$. Likewise, as shown in Fig. 2B, the concentration of creatinine in plasma significantly increased in the $\mathrm{CP}+$ saline group compared with the saline one $(\mathrm{P}<0.01)$, and in the $\mathrm{CP}+\mathrm{CeO}_{2} \mathrm{NPs}$ group compared with the $\mathrm{CP}+$ saline $(\mathrm{P}<0.05)$ or $\mathrm{CeO}_{2}$ NPs group $(\mathrm{P}<0.01)$. Fig. $2 \mathrm{C}$ displays that creatinine clearance was significantly reduced in rats treated with $\mathrm{CP}+$ saline compared with those treated with saline $(\mathrm{P}<0.001)$, and in rats treated with $\mathrm{CP}+\mathrm{CeO}_{2}$ NPs compared with those treated with either $\mathrm{CP}+$ saline $(\mathrm{P}<0.05)$ or those treated $\mathrm{CeO}_{2}$ NPs alone $(\mathrm{P}<0.001)$.

\section{KIM-1, IL-6, TNF $\alpha$ and GSH concentrations} in kidney homogenates

Fig. 3A illustrates that treatment with $\mathrm{CP}+$ saline significantly increased the concentration of KIM-1 compared with that of the saline-treated group $(\mathrm{P}<0.01)$. Simultaneous treatment with $\mathrm{CP}$ and $\mathrm{CeO}_{2} \mathrm{NPs}$ significantly augmented the concentration of KIM-1 in kidney homogenates compared with either $\mathrm{CP}+$ saline group $(\mathrm{P}<0.05)$ or $\mathrm{CeO}_{2} \mathrm{NPs}$ group $(\mathrm{P}<0.001)$. Fig. $3 \mathrm{~B}$ and $3 \mathrm{C}$ show that the concentrations of IL- 6 and TNF $\alpha$ in kidney homogenates were significantly increased in $\mathrm{CeO}_{2} \mathrm{NPs}$ group compared with saline group. Moreover, the concentrations of IL-6 and $\mathrm{TNF} \alpha$ were significantly increased in $\mathrm{CP}$ + saline group compared with saline group, and in $\mathrm{CP}+\mathrm{CeO}_{2}$ NPs compared with either $\mathrm{CP}+$ saline or $\mathrm{CeO}_{2} \mathrm{NPs}$ group. Fig. 3D shows that compared with saline group, treatment with $\mathrm{CeO}_{2}$ NPs induced a significant increase in GSH levels. Moreover, the levels of GSH were also significantly augmented in $\mathrm{CP}+$ saline group versus saline group and, in $\mathrm{CP}$ $+\mathrm{CeO}_{2} \mathrm{NPs}$ group versus either $\mathrm{CP}+$ saline group or $\mathrm{CeO}_{2} \mathrm{NPs}$ group.

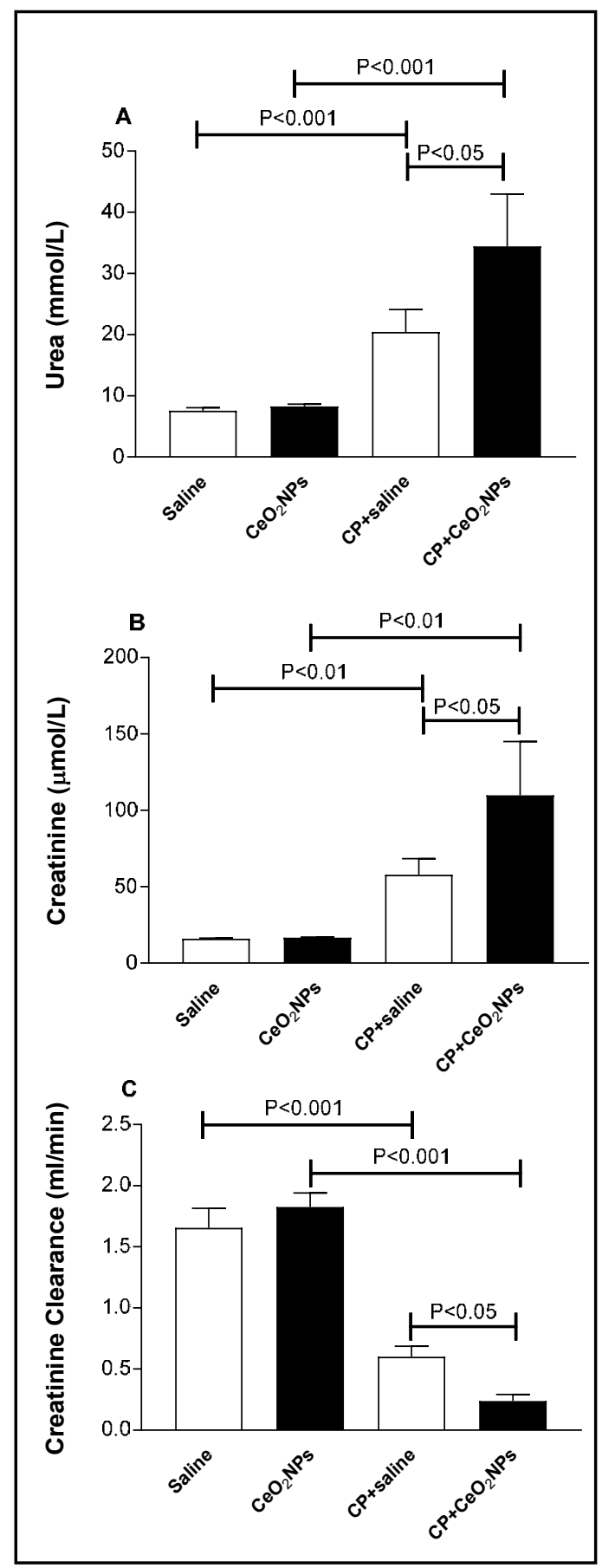

Fig. 2. Plasma concentrations of urea (A) and creatinine (B) and creatinine clearance (C) in Wistar rats intratracheally instilled with either saline (control) or cerium oxide nanoparticles $\left(\mathrm{CeO}_{2}\right.$ NPs) with or without cisplatin (CP) administration. Data are mean \pm SEM. Urea: saline $(n=8), \mathrm{CeO}_{2} \mathrm{NPs}$ $(n=8), C P+$ saline $(n=6)$ and $\mathrm{CP}+\mathrm{CeO}_{2}$ NPs $(n=6)$. Creatinine and creatinine clearance: saline $(n=8)$, $\mathrm{CeO}_{2} \mathrm{NPs}(\mathrm{n}=8), \mathrm{CP}+$ saline $(\mathrm{n}=8)$ and $\mathrm{CP}+\mathrm{CeO}_{2} \mathrm{NPs}$ $(n=7)$. 


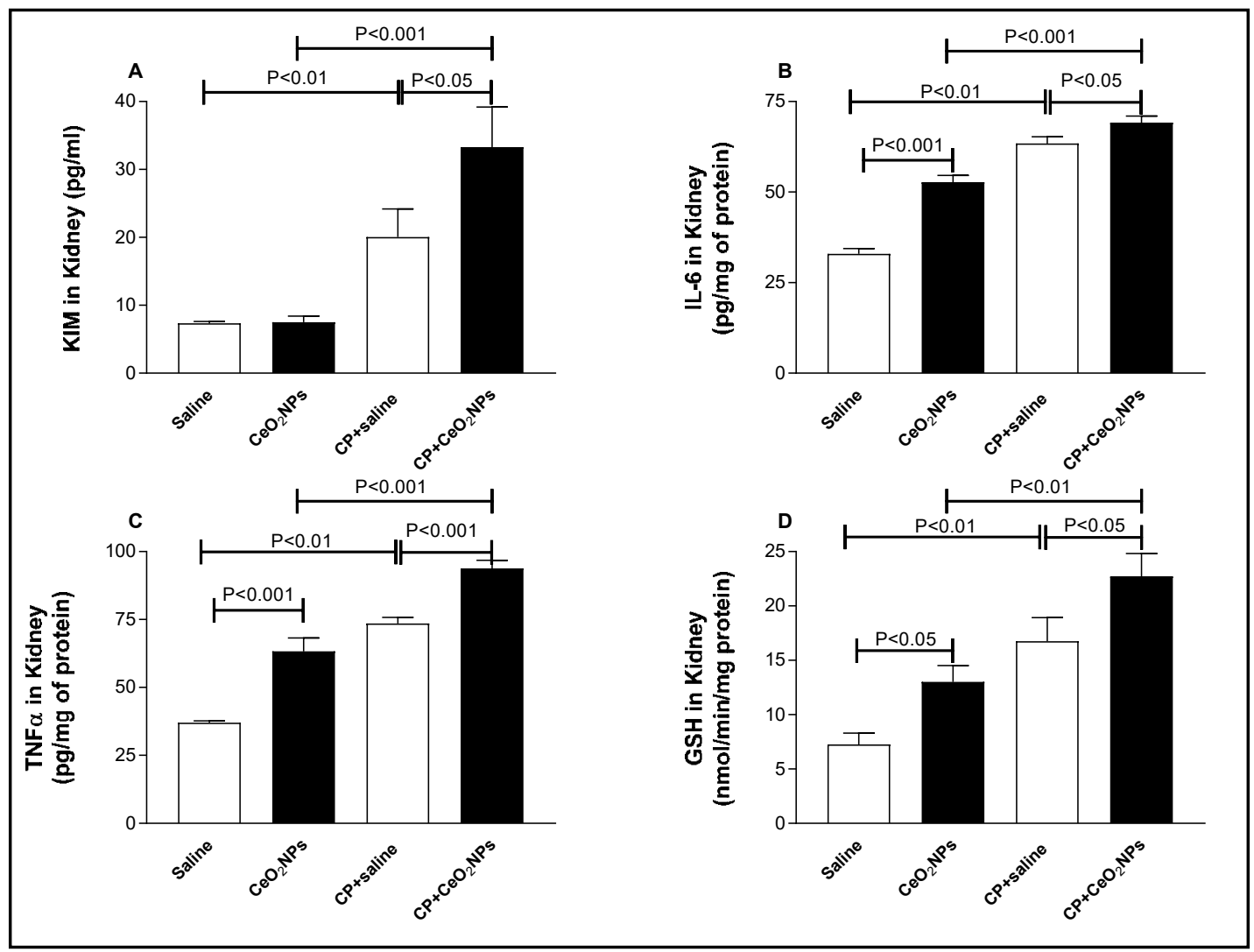

Fig. 3. Kidney injury molecule 1 (KIM-1; A), interleukin 6 (IL-6, B), tumor necrosis factor $\alpha$ (TNF $\alpha, \mathrm{C})$ and glutathione (D) in Wistar rats intratracheally instilled with either saline (control) or cerium oxide nanoparticles $\left(\mathrm{CeO}_{2} \mathrm{NPs}\right)$ with or without cisplatin (CP) administration. Data are mean \pm SEM. KIM: saline ( $n=8), \mathrm{CeO}_{2} \mathrm{NPs}(\mathrm{n}=8), \mathrm{CP}+$ saline $(\mathrm{n}=7)$ and $\mathrm{CP}+\mathrm{CeO}_{2} \mathrm{NPs}(\mathrm{n}=6)$. IL-6: saline $(\mathrm{n}=8), \mathrm{CeO}_{2} \mathrm{NPs}(\mathrm{n}=8)$, $\mathrm{CP}+$ saline $(\mathrm{n}=7)$ and $\mathrm{CP}+\mathrm{CeO}_{2} \mathrm{NPs}(\mathrm{n}=8) . \mathrm{TNF} \alpha$ : saline $(\mathrm{n}=8), \mathrm{CeO}_{2} \mathrm{NPs}(\mathrm{n}=8), \mathrm{CP}+$ saline $(\mathrm{n}=8)$ and $\mathrm{CP}+\mathrm{CeO}_{2}$ NPs (n=8). GSH: saline $(n=6), \mathrm{CeO}_{2} \mathrm{NPs}(\mathrm{n}=6), \mathrm{CP}+$ saline $(\mathrm{n}=6)$ and $\mathrm{CP}+\mathrm{CeO}_{2} \mathrm{NPs}(\mathrm{n}=6)$.

\section{DNA damage in the kidney}

Fig. 4 depicts the evaluation of DNA injury in the kidney by the Comet assay. Compared with saline group, pulmonary exposure to $\mathrm{CeO}_{2}$ NPs induced a significant increase in DNA damage $(\mathrm{P}<0.05)$. DNA damage was significantly augmented in $\mathrm{CP}+$ saline group compared with saline group $(\mathrm{P}<0.05)$. Furthermore, the DNA damage observed in $\mathrm{CeO}_{2} \mathrm{NPs}+\mathrm{CP}$ group was significantly higher compared with either $\mathrm{CP}+$ saline $(\mathrm{P}<0.01)$ or $\mathrm{CeO}_{2} \mathrm{NPs}$ alone $(\mathrm{P}<0.01)$.

\section{Kidney histopathology}

Fig. 5 and Table 1 illustrate kidney histopathology and the percentage and scores for tubular injury in the four studied groups. Saline-treated group showed normal kidney architecture and histology and was given a score of 0 (Fig. 5A-B). In CP + saline group (Fig. $5 C$-D), there was an acute tubular injury in $37.50 \pm 2.49 \%$ of examined tissue areas (score 2) which showed the presence of tubular distention with necrotic material involving loss of brush border, tubular dilatation, tubular cells necrosis, tubular nuclear pyknosis, tubular nuclear enlargement with hyperchromasia, tubular cells flattening, macrophages within the lumen, epithelial cells within the lumen and intra-luminal eosinophilic material. In $\mathrm{CeO}_{2} \mathrm{NPs}$ group (Fig. 5E-F), there were focal areas of acute tubular injury accounting $7.37 \pm 0.94$ of total examined areas involving proximal convoluted tubules characterized by mild tubular dilatation, intracytoplasmic aggregates of giant lysosomes within tubular cells, epithelial cells falling within the lumen of tubular cells and intratubular secretion. In $\mathrm{CP}+\mathrm{CeO}_{2} \mathrm{NPs}$ group 
(Fig. 5G-H), there was an increased frequency of acute tubular injury when compared with either CP + saline group or $\mathrm{CeO}_{2} \mathrm{NPs}$ group. The acute tubular injury observed CP + $\mathrm{CeO}_{2}$ NPs involved $58.63 \pm 6.27 \%$ of examined areas (score 3 ). The latter showed the presence of tubular distention with necrotic material involving, loss of brush border, tubular dilatation, tubular cells necrosis, tubular nuclear pyknosis, tubular nuclear enlargement with hyperchromasia, tubular cells flattening, macrophages within the lumen, epithelial cells within the lumen and intra-luminal eosinophilic material.

\section{Lung histopathology}

Saline-treated group showed

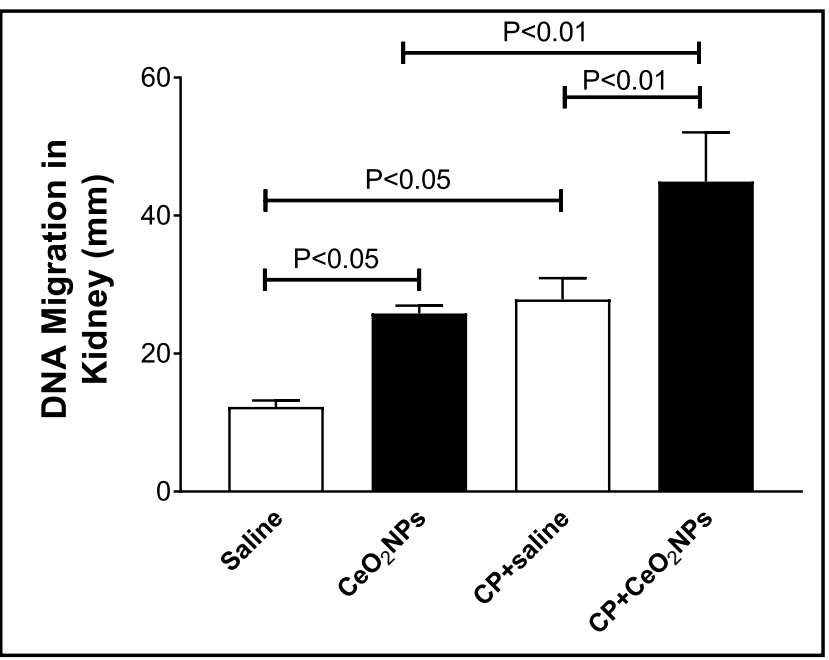

Fig. 4. DNA migration ( $\mathrm{mm}$ ) in the kidney tissues evaluated by Comet assay, in Wistar rats intratracheally instilled with either saline (control) or cerium oxide nanoparticles $\left(\mathrm{CeO}_{2} \mathrm{NPs}\right)$ with or without cisplatin (CP) administration. Data are mean \pm SEM $(n=5)$. normal lung architecture with unremarkable changes (Fig. 6A). In $\mathrm{CP}+$ saline group, there was a moderate widening of interalveolar interstitial spaces with mixed inflammatory cells consisting of neutrophil polymorphs, lymphocytes and macrophages (Fig. 6B). In $\mathrm{CeO}_{2}$ NPs (Fig. 6C), there was focal mild widening of interalveolar interstitial spaces with mixed inflammatory cells consisting of neutrophil polymorphs, lymphocytes and macrophages. In $\mathrm{CP}+\mathrm{CeO}_{2}$ NPs (Fig. 6D), there was a severe widening of interalveolar interstitial spaces with mixed inflammatory cells consisting of neutrophil polymorphs, lymphocytes and macrophages.

\section{IL-6, TNF $\alpha$, catalase and total NO levels in lung homogenates}

Fig. 7A-B illustrates that treatment with $\mathrm{CP}+\mathrm{CeO}_{2}$ NPs significantly increased the concentration of IL- 6 and TNF $\alpha$ compared with $\mathrm{CP}+$ saline group or $\mathrm{CeO}_{2} \mathrm{NPs}$ group. On the other hand, the activity of catalase was significantly reduced in $\mathrm{CP}+\mathrm{CeO}_{2} \mathrm{NPs}$ compared with either $\mathrm{CP}+$ saline group or $\mathrm{CeO}_{2} \mathrm{NPs}$ group (Fig. 7C). Moreover, the catalase activity decreased significantly in rats treated with $\mathrm{CeO}_{2} \mathrm{NPs}$ compared with those given saline, and in rats treated with saline $+\mathrm{CP}$ compared with those treated with saline (Fig. 7C). The total $\mathrm{NO}$ activity was significantly reduced in $\mathrm{CP}+\mathrm{CeO}_{2} \mathrm{NPs}$ compared with either $\mathrm{CP}+$ saline group or $\mathrm{CeO}_{2} \mathrm{NPs}$ group (Fig. 7C-D).

\section{DNA damage in the lung}

As shown in Fig. 8, compared with saline group, treatment with $\mathrm{CeO}_{2}$ NPs induced a significant increase in DNA damage $(\mathrm{P}<0.001)$. DNA damage was significantly increased in $\mathrm{CP}+$ saline group compared with saline group $(\mathrm{P}<0.001)$. Additionally, the DNA damage seen in $\mathrm{CeO}_{2} \mathrm{NPS}+\mathrm{CP}$ group was significantly higher compared with either $\mathrm{CP}+$ saline $(\mathrm{P}<0.05)$ or $\mathrm{CeO}_{2}$ NPs alone $(\mathrm{P}<0.001)$. 


\section{Cellular Physiology Cell Physiol Biochem 2019;52:439-454

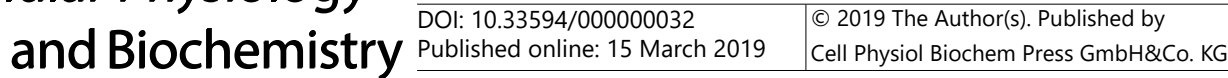

Fig. 5. A-H: representative light microscopy sections of $\mathrm{H}$ and $\mathrm{E}$ stained kidney tissues of Wistar rats intratracheally instilled with either saline (control) or cerium oxide nanoparticles $\left(\mathrm{CeO}_{2} \mathrm{NPs}\right)$ with or without cisplatin (CP) administration. A and B: representative kidney sections obtained from saline-treated rats showing normal kidney architecture and histology. There was no tubular injury $(0 \%, \mathrm{n}=6)$ in the examined section. $\mathrm{C}$ and D: representative kidney sections obtained from CP + saline-treated rats showing the presence of acute tubular injury in $37.50 \pm 2.49 \%(\mathrm{n}=6)$ of examined tissue areas (thin arrows) (score 2). $\mathrm{E}$ and $\mathrm{F}$ : representative kidney sections obtained from $\mathrm{CeO}_{2} \mathrm{NPs}$-treated rats showing the presence of focal acute tubular injury in $7.37 \pm 0.94 \%(n=6)$ of examined tissue areas with intracytoplasmic aggregates of giant lysosomes within proximal tubular cells (arrowhead), and

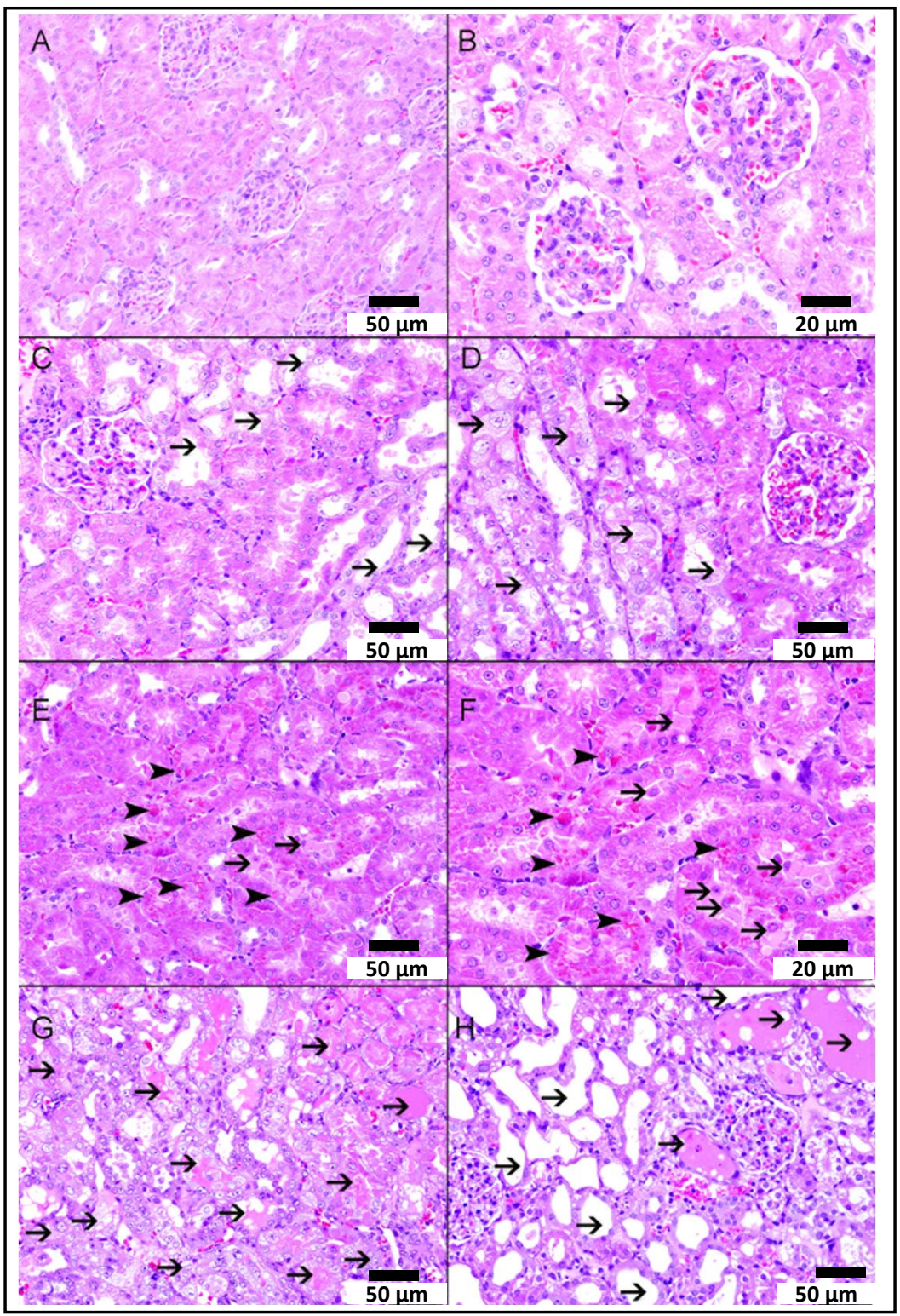
epithelial cells falling within the lumen of tubular cells (thin arrow) (score 1). G and H: representative kidney sections obtained from $\mathrm{CP}+\mathrm{CeO}_{2} \mathrm{NPs}$-treated rats showing the presence higher percentage of acute tubular injury when compared with either $\mathrm{CP}+$ saline group or $\mathrm{CeO}_{2} \mathrm{NPs}$ group. There is acute tubular injury (thin arrow) involving $58.63 \pm 6.27 \%(n=6)$ of examined areas (score 3 ).

Table 1. Semi quantitative assessment of acute tubular injury in rats treated with either saline (control) or cerium oxide nanoparticles $\left(\mathrm{CeO}_{2} \mathrm{NPs}, 1 \mathrm{mg} / \mathrm{kg}\right)$ with or without cisplatin $(\mathrm{CP}, 6 \mathrm{mg} / \mathrm{kg})$ administration. ${ }^{\text {a }} \mathrm{P}<0.0001$ compared with the saline-treated group. ${ }^{\mathrm{b}} \mathrm{P}<0.0001$ compared with the $\mathrm{CeO}_{2} \mathrm{NPs}$-treated group. ${ }^{\mathrm{c}} \mathrm{P}<0.001$ compared with the $\mathrm{CP}+$ saline-treated group. Data are presented as mean $\pm \mathrm{SEM}(\mathrm{n}=6$ for each group). Statistical analysis was performed by Newman-Keuls test

\begin{tabular}{lcc}
\hline Groups & Mean \% of acute tubular injury \pm SEM & Score of acute tubular injury \\
\hline Saline & 0 & 0 \\
$\mathrm{CP}+$ saline & $37.50 \pm 2.49 \mathrm{a}$ & 2 \\
$\mathrm{CeO}_{2} \mathrm{NPs}$ & $7.37 \pm 0.94$ & 1 \\
$\mathrm{CP}+\mathrm{CeO}_{2} \mathrm{NPs}$ & $58.63 \pm 6.27 \mathrm{a}, \mathrm{b}, \mathrm{c}$ & 3 \\
\hline
\end{tabular}




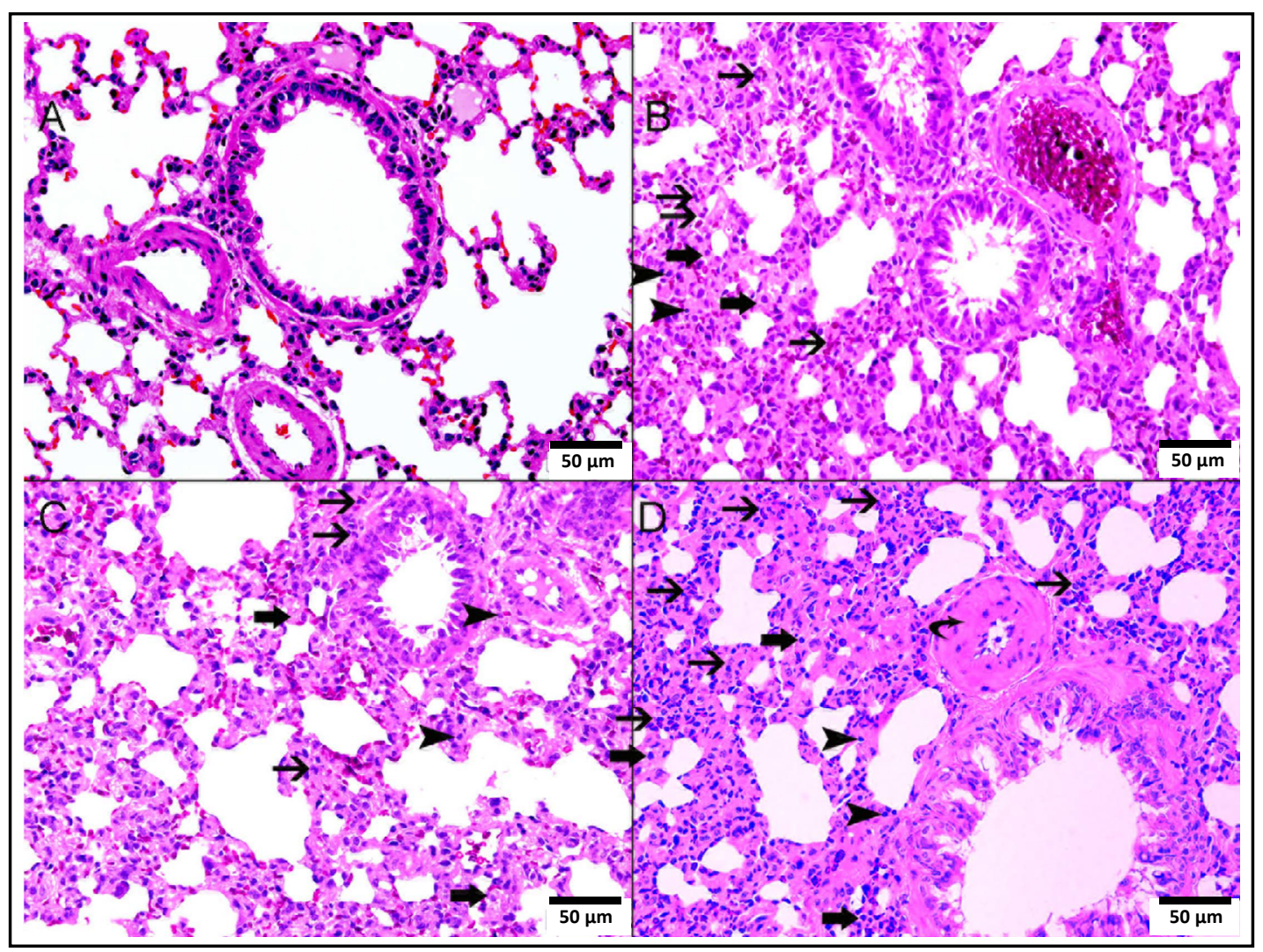

Fig. 6. A-D: representative light microscopy sections of $\mathrm{H}$ and $\mathrm{E}$ stained lung tissues of Wistar rats intratracheally instilled with either saline (control) or cerium oxide nanoparticles $\left(\mathrm{CeO}_{2} \mathrm{NPs}\right)$ with or without cisplatin (CP) administration. A: representative lung sections obtained from saline-treated rats showing normal lung architecture and histology. B: representative lung sections obtained from $\mathrm{CP}+$ salinetreated rats showing the presence of moderate widening of interalveolar interstitial spaces with mixed inflammatory cells consisting of neutrophil polymorphs (thin arrow), lymphocytes (arrowhead) and

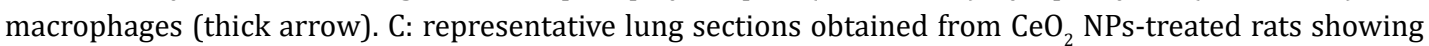
the presence of foci of mild widening of interalveolar interstitial spaces with mixed inflammatory cells consisting of neutrophil polymorphs (thin arrow), lymphocytes (arrowhead) and macrophages (thick arrow). D: representative lung sections obtained from $\mathrm{CP}+\mathrm{CeO}_{2} \mathrm{NPs}$-treated rats showing the presence severe widening of interalveolar interstitial spaces with mixed inflammatory cells consisting of neutrophil polymorphs (thin arrow), lymphocytes (arrowhead) and macrophages (thick arrow).

\section{Discussion}

$\mathrm{CP}$ is one of the most effective anticancer drugs used in the therapy of a variety of solid tumours [34], mostly owing to its high efficacy and low cost. CP efficacy increases with dose, but high doses are associated with many severe adverse effects, particularly nephrotoxicity, including apoptosis, inflammation, necrosis and death in proximal tubules and collecting ducts [34]. The mechanism underlying the side effects induced by CP is not fully understood but it has been suggested to be related to oxidative stress and inflammation [35]. Several studies have established the occurrence of renal failure with a single i.p. dose of $6 \mathrm{mg} / \mathrm{kg}$ in rats $[17,22,36]$. The dose of $\mathrm{CeO} 2 \mathrm{NPs}$ tested here has been chosen from earlier studies using animal models of i.t. or oropharyngeal instillation of $\mathrm{CeO} 2 \mathrm{NPs}$ and evaluating their impact on lung inflammation, oxidative stress, thrombosis and ischemia-reperfusion injury in mice and rats $[10,12,13,37]$. Here, the exposure of rats to CeO2 NPs was performed by i.t. instillation technique which offers a more accurate way of administration, since rats are obligate nose breathers that filter most inhaled particles [38]. 


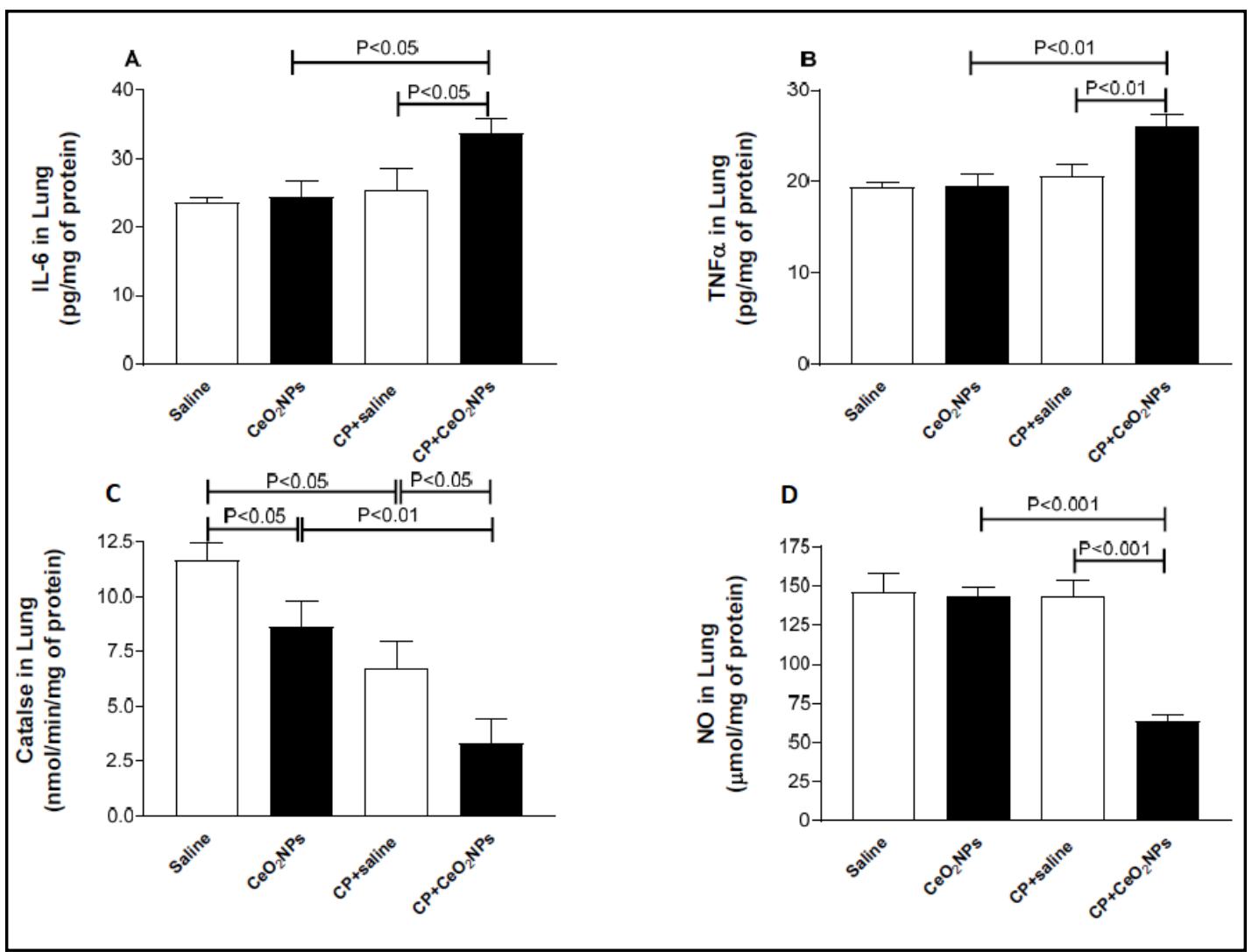

Fig. 7. interleukin 6 (IL-6, A), tumor necrosis factor $\alpha(\mathrm{TNF} \alpha, \mathrm{B})$, catalase (C) and total nitric oxide (NO, D) levels in lung homogenates of Wistar rats intratracheally instilled with either saline (control) or cerium oxide nanoparticles $\left(\mathrm{CeO}_{2} \mathrm{NPs}\right)$ with or without cisplatin (CP) administration. Data are mean \pm SEM. IL-6: saline (n=6), $\mathrm{CeO}_{2} \mathrm{NPs}(\mathrm{n}=6), \mathrm{CP}+$ saline $(\mathrm{n}=6)$ and $\mathrm{CP}+\mathrm{CeO}_{2} \mathrm{NPs}(\mathrm{n}=6) . \mathrm{TNF} \alpha$ : saline $(\mathrm{n}=7), \mathrm{CeO}_{2} \mathrm{NPs}(\mathrm{n}=7)$, $\mathrm{CP}+$ saline $(\mathrm{n}=6)$ and $\mathrm{CP}+\mathrm{CeO}_{2} \mathrm{NPs}(\mathrm{n}=6)$. Catalase: saline $(\mathrm{n}=6), \mathrm{CeO}_{2} \mathrm{NPs}(\mathrm{n}=5), \mathrm{CP}+$ saline $(\mathrm{n}=5)$ and $\mathrm{CP}+$ $\mathrm{CeO}_{2}$ NPs $(n=5)$. NO: saline $(n=8), \mathrm{CeO}_{2} \mathrm{NPs}(\mathrm{n}=8), \mathrm{CP}+$ saline $(\mathrm{n}=8)$ and $\mathrm{CP}+\mathrm{CeO}_{2} \mathrm{NPs}(\mathrm{n}=8)$.

Fig. 8. DNA migration ( $\mathrm{mm})$ in the lung tissues evaluated by Comet assay, in Wistar rats intratracheally instilled with either saline (control) or cerium oxide nanoparticles $\left(\mathrm{CeO}_{2} \mathrm{NPs}\right)$ with or without cisplatin (CP) administration. Data are mean \pm SEM. Saline ( $n=5), \mathrm{CeO}_{2} \mathrm{NPs}(\mathrm{n}=4)$, $\mathrm{CP}+$ saline $(\mathrm{n}=5)$ and $\mathrm{CP}+\mathrm{CeO}_{2} \mathrm{NPs}$ $(\mathrm{n}=6)$.

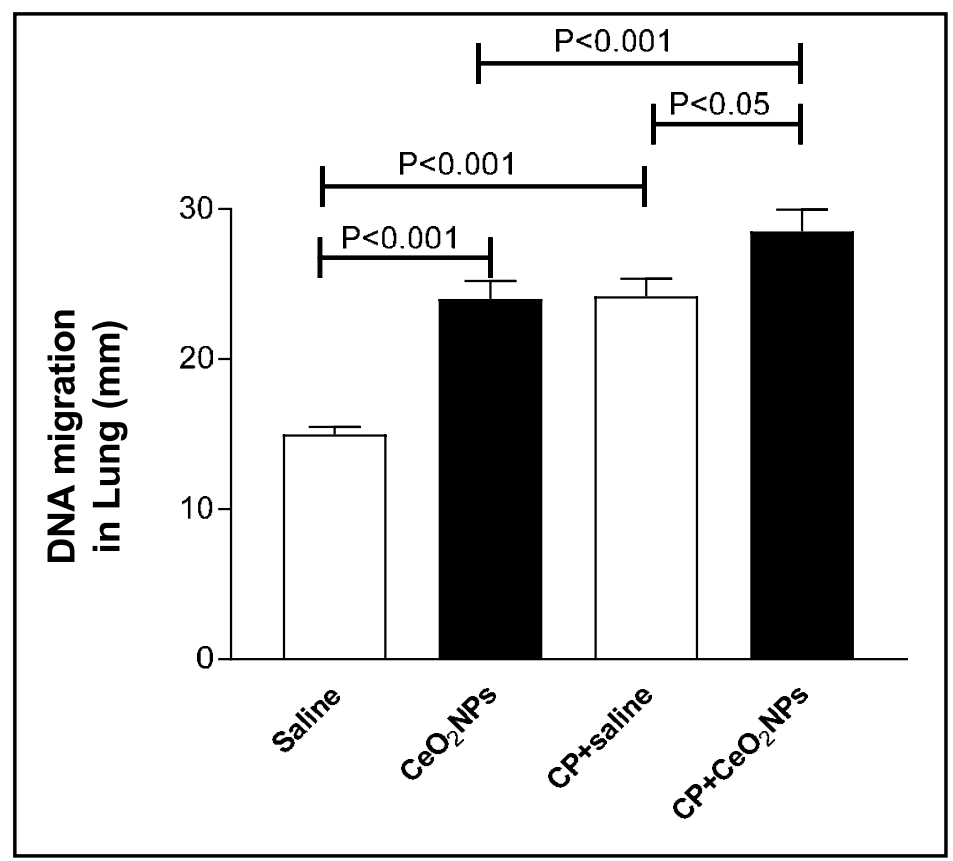


There is discrepancy in the literature regarding the effects of CeO2 NPs. In fact, while some studies reported that these nanoparticles are capable of abrogating inflammation and oxidative stress in vitro and in vivo $[8,39]$, several others studies reported their ability to induce inflammation, oxidative stress, DNA damage and apoptosis in various organs $[9,10$, $12,13]$.

It has been shown that inhaled nanoparticles $(<30 \mathrm{~nm}$ in diameter $)$ can cross the alveolar capillary barrier and reach the blood [40-42]. The latter have been reported to be filtered and excreted by the kidneys and preferentially deposit at sites of vascular inflammation in both experimental animals and healthy subjects [40]. Moreover, we have recently showed that pulmonary exposure to CeO2NPs induce inflammation, oxidative stress and DNA damage in different organs including the kidney $[12,13]$, thus, in the preset study, we thought it was important to assess if pulmonary exposure to CeO2NPs is capable of aggravating acute renal injury induced by CP. This approach is particularly relevant since it is well-established that patients with renal disease develop states of increased inflammation and oxidative stress which can make them more susceptible to the effects of inhaled nanoparticles [43].

Our data show a decrease in body weight by around $17 \%$ after $\mathrm{CP}$ administration and that the combination of CP and CeO2 NPs further reduced it to $20 \%$ but the difference between $\mathrm{CP}+$ saline and $\mathrm{CP}+\mathrm{CeO} 2 \mathrm{NPs}$ groups was statistically insignificant. Moreover, we found that the relative kidney weight, water intake and urine volume were all increased in $\mathrm{CP}+$ saline compared with saline and that the concomitant administration of CP + CeO2 NPs has aggravated these 3 variables compared with either $\mathrm{CP}+$ saline or $\mathrm{CeO} 2 \mathrm{NPs}$. The reduction of body weight and increase in kidney relative weight can be ascribed to the renal tubular damage, and subsequent deterioration of the capacity of tubular cells to reabsorb water, causing polyuria leading to dehydration, which can explain the ensuing increase of water intake. In the present study, the worsening of kidney function in rats exposed to $\mathrm{CP}$ and $\mathrm{CeO} 2$ NPs was confirmed by the significant increase in the concentrations of creatinine and urea in plasma and significant decline of creatinine clearance compared with rats treated with either $\mathrm{CP}+$ saline or $\mathrm{CeO} 2 \mathrm{NPs}$. Such findings have not been reported before. It has been previously shown that the combination of CP + DEPs $(1 \mathrm{mg} / \mathrm{kg})$ aggravated the serum concentration of urea and creatinine compared with either CP + saline or DEPs [17]. However, no aggravating effect was observed for urine volume in CP + DEPs compared with either CP + saline or DEPs [17].

In order to investigate the mechanisms by which the combination of $\mathrm{CP}$ and $\mathrm{CeO}_{2} \mathrm{NPs}$ exerts their toxic effects, we measured, in kidney homogenates, several traditional and novel markers of kidney injury (KIM-1), inflammation (TNF $\alpha$ and IL-6) and oxidative stress (GSH). KIM-1 is very sensitive (95\%) biomarker of early renal injury expressed by renal tubular epithelium and its expression has been reported to persist until kidney recovery [44]. The increase of KIM-1 has been reported in rats treated with CP [45]. Our data show that the concentration of KIM-1 was increased in kidney homogenate of rats given CP and saline compared with saline-treated ones. Interestingly, we found that the administration of both $\mathrm{CP}$ and $\mathrm{CeO}_{2}$ NPs significantly elevated the concentrations of KIM-1 in kidney homogenates compared with rats given either $\mathrm{CP}$ and saline or $\mathrm{CeO}_{2}$ NPs. Similarly, the concentrations of the pro-inflammatory cytokines IL- 6 and TNF $\alpha$ were both significantly higher in rats treated with $\mathrm{CP}$ and $\mathrm{CeO}_{2} \mathrm{NPs}$ compared with those given either $\mathrm{CP}$ and saline or $\mathrm{CeO}_{2} \mathrm{NPs}$. Along with the increase in KIM-1, IL- 6 and TNF $\alpha$, our data show that the levels of the antioxidant GSH were also significantly increased in $\mathrm{CP}+\mathrm{CeO}_{2} \mathrm{NPs}$ compared with either $\mathrm{CP}+$ saline or $\mathrm{CeO}_{2} \mathrm{NPs}$, indicating the occurrence of adaptive reaction in the kidney to counterbalance the potentially damaging action of oxygen radicals induced by the concomitant administration of $\mathrm{CP}$ and $\mathrm{CeO}_{2} \mathrm{NPs}$. The latter findings suggest the aggravating effects of $\mathrm{CP}$ and $\mathrm{CeO}_{2} \mathrm{NPs}$ involve inflammation and oxidative stress. It has been reported that oxidative stress and inflammation are considered to be the driving factors in CP-induced nephrotoxicity and the use of natural antioxidants and anti-inflammatory agents such as emodin or ellagic acid alleviate these effects $[20,45]$. We have recently demonstrated in mice that pulmonary exposure to $\mathrm{CeO}_{2}$ NPs induces oxidative stress and DNA injury in the kidney [13]. Here, we 


\section{Cellular Physiology Cell Physiol Biochem 2019;52:439-454 \\ \begin{tabular}{ll|l} 
and Biochemistry $\begin{array}{l}\text { DOl: 10.33594/000000032 } \\
\text { Published online: } 15 \text { March 2019 }\end{array}$ & $\begin{array}{l}\text { O } 2019 \text { The Author(s). Published by } \\
\text { Cell Physiol Biochem Press GmbH\&Co. KG }\end{array}$ \\
\cline { 2 - 3 } &
\end{tabular} \\ Nemmar et al.: Cerium Oxide Nanoparticles and Acute Kidney Injury}

confirmed the occurrence of DNA damage in rats given $\mathrm{CeO}_{2} \mathrm{NPs}$ and those treated with both $\mathrm{CP}$ and saline. Interestingly, we found that the DNA damage is exacerbated in rats given both $\mathrm{CP}$ and $\mathrm{CeO}_{2} \mathrm{NPs}$ compared with either $\mathrm{CP}+$ saline group or $\mathrm{CeO}_{2} \mathrm{NPs}$ group. The latter result could be explained by the potentiation of injury, inflammation and oxidative stress exerted by the combination of $\mathrm{CP}$ and $\mathrm{CeO}_{2} \mathrm{NPs}$. Histopathological analysis of the kidneys of rats given $\mathrm{CeO}_{2}$ revealed the presence of focal areas of acute tubular injury (7\% of total examined areas; score 1) involving proximal convoluted tubules. The treatment with CP and saline induced significantly more acute tubular injury (37\% of total examined areas; score 2). Remarkably, the association of $\mathrm{CP}$ and $\mathrm{CeO}_{2} \mathrm{NPs}$ caused a much higher increase in extent of acute tubular injury (58\% of total examined areas; score 3). Previously, in a rat model of AKI induced by CP administration, we showed no effect on kidney histology of pulmonary exposure to DEPs $(1 \mathrm{mg} / \mathrm{kg})$, and the administration of $\mathrm{CP}+$ saline or CP + DEPs induced comparable degree of acute tubular necrosis [17]. Thus, the current data suggest that at the same dose, i.e. $1 \mathrm{mg} / \mathrm{kg}, \mathrm{CeO}_{2} \mathrm{NPs}$ alone or in combination with $\mathrm{CP}$ has more nephrotoxic effects than DEP alone or in combination with CP. The latter could be explained by the small homogenous size of $\mathrm{CeO}_{2} \mathrm{NPs}(20 \mathrm{~nm})$ as compared with DEP (geometric mean aerodynamic diameter of $215 \mathrm{~nm}$ ) [46]. The small size and large surface area of $\mathrm{CeO}_{2}$ NPs allow them to cross different biological barriers and exert more toxicity $[2,47,48]$.

Various studies have shown the presence of a close association between kidney injury and lung diseases [14]. This relationship takes place as a result of the occurrence of systemic inflammation and oxidative stress which subsequently trigger lung damage [14]. Primary kidney disease can induce inflammation and oxidative stress which can affect the lung, and vice versa kidney dysfunction can happen as a result of lung injury and the release of mediators of inflammation and reactive oxygen species in the blood which can reach the kidneys $[14,49]$. Our lung histology data show that compared with saline group, the rats given either $\mathrm{CeO}_{2} \mathrm{NPs}$ alone or $\mathrm{CP}+$ saline displayed the presence of lung inflammation. Moreover, rats given both $\mathrm{CP}+\mathrm{CeO}_{2} \mathrm{NPs}$ revealed a substantial potentiation of pulmonary inflammation. Likewise, the concentrations of markers of inflammation including IL-6 and TNF $\alpha$ in lung homogenates were significantly elevated by the combination of CP and $\mathrm{CeO}_{2}$ NPs compared with either $\mathrm{CP}+$ saline or $\mathrm{CeO}_{2} \mathrm{NPs}$. It has been shown that oxidative stress induces a decrease of bioactivity of $\mathrm{NO}$ [50]. Here, we show that the levels of NO were significantly decreased in lung homogenates of $\mathrm{CP}+\mathrm{CeO}_{2} \mathrm{NPs}$ compared with either $\mathrm{CP}+$ saline or $\mathrm{CeO}_{2} \mathrm{NPs}$. Moreover, the measurement of the antioxidant enzyme catalase exhibited its depletion in $\mathrm{CeO}_{2} \mathrm{NPs}$-treated group and $\mathrm{CP}+$ saline group compared with saline group. $\mathrm{A}$ significantly higher decline in catalase activity was seen in rats given both $\mathrm{CP}$ and $\mathrm{CeO}_{2} \mathrm{NPs}$. The latter finding indicates that this antioxidant has been consumed as a result of oxidative stress [51]. Additionally, compared with saline group, we found the presence of lung DNA damage in rats treated $\mathrm{CeO}_{2}$ NPs and those given both CP and saline. Remarkably, the DNA damage was found to be worsened in rats given both $\mathrm{CP}$ and $\mathrm{CeO}_{2} \mathrm{NPs}$. Such finding has never been reported before. Lung DNA damage has been reported in adenine-induced chronic kidney disease in mice, and was explained by the occurrence of oxidative stress [51]. The results obtained presently in the lung confirm previous clinical and experimental studies that kidney injury cause pulmonary pathophysiological effects [14, 17, 43, 51], and hence indicate that pulmonary exposure to $\mathrm{CeO}_{2} \mathrm{NPs}$ exacerbates the kidney injury.

\section{Conclusion}

Our data provide novel experimental evidence that pulmonary exposure to $\mathrm{CeO}_{2} \mathrm{NPs}$ in animal model of renal failure exacerbates both kidney and lung injury, and highlight the importance of performing a thorough evaluation of the toxicity of nanoparticles, particularly in animal models of human diseases. 


\section{Cellular Physiology Cell Physiol Biochem 2019;52:439-454 \\ \begin{tabular}{ll|l} 
and Biochemistry & $\begin{array}{l}\text { DOl: 10.33594/000000032 } \\
\text { Published online: } 15 \text { March 2019 }\end{array}$ & $\begin{array}{l}\text { O } 2019 \text { The Author(s). Published by } \\
\text { Cell Physiol Biochem Press GmbH\&Co. KG }\end{array}$ \\
\cline { 2 - 3 } &
\end{tabular} \\ Nemmar et al.: Cerium Oxide Nanoparticles and Acute Kidney Injury}

\section{Acknowledgements}

This work was supported by funds of Summer Undergraduate Research Experiences Program, the College of Medicine and Health Sciences grant, United Arab Emirates University (UAEU) and by a joint UAEU-SQU grant.

\section{Disclosure Statement}

The authors declare to have no competing interests.

\section{References}

1 Radomska A, Leszczyszyn J, Radomski MW: The Nanopharmacology and Nanotoxicology of Nanomaterials: New Opportunities and Challenges. Adv Clin Exp Med 2016;25:151-162.

2 Oberdorster G: Safety assessment for nanotechnology and nanomedicine: concepts of nanotoxicology. J Intern Med 2010;267:89-105.

3 Park B, Donaldson K, Duffin R, Tran L, Kelly F, Mudway I, Morin JP, Guest R, Jenkinson P, Samaras Z, Giannouli M, Kouridis H, Martin P: Hazard and risk assessment of a nanoparticulate cerium oxide-based diesel fuel additive - a case study. Inhal Toxicol 2008;20:547-566.

$4 \quad$ Health Effect Institute (HEI): Evaluation of human health risk from cerium added to diesel fuel. Health Effects Institute, Boston, MA. Communication 9, 2001.

URL: https://www.healtheffects.org/system/files/Cerium.pdf.

5 Wakefield G, Wu X, Gardener M, Park B, Anderson S: Envirox ${ }^{\mathrm{TM}}$ fuel-borne catalyst: developing and launching a nano-fuel additive. Tech Anal Strat Manag 2008; DOI:10.1080/09537320701726825.

6 Selvan AM, Anand V, Udayakumar MRB: Effects of cerium oxide nanoparticle addition in diesel and dieselbiodiesel-ethanol blends on the performance and emission characteristics of a CI engine. ARPN J Eng Appl Sci 2009;4:1-6.

- 7 Cassee FR, van Balen EC, Singh C, Green D, Muijser H, Weinstein J, Dreher K: Exposure, health and ecological effects review of engineered nanoscale cerium and cerium oxide associated with its use as a fuel additive. Crit Rev Toxicol 2011;41:213-229.

- 8 Hussain S, Al-Nsour F, Rice AB, Marshburn J, Yingling B, Ji Z, Zink JI, Walker NJ, Garantziotis S: Cerium dioxide nanoparticles induce apoptosis and autophagy in human peripheral blood monocytes. ACS Nano 2012;6:5820-5829.

- 9 Snow SJ, Mcgee J, Miller DB, Bass V, Schladweiler MC, Thomas RF, Krantz T, King C, Ledbetter AD, Richards J, Weinstein JP, Conner T, Willis R, Linak WP, Nash D, Wood CE, Elmore SA, Morrison JP, Johnson CL, Gilmour MI, et al.: Inhaled diesel emissions generated with cerium oxide nanoparticle fuel additive induce adverse pulmonary and systemic effects. Toxicol Sci 2014;142:403-417.

- 10 Ma JY, Zhao H, Mercer RR, Barger M, Rao M, Meighan T, Schwegler-Berry D, Castranova V, Ma JK: Cerium oxide nanoparticle-induced pulmonary inflammation and alveolar macrophage functional change in rats. Nanotoxicology 2011;5:312-325.

- 11 He X, Zhang H, Ma Y, Bai W, Zhang Z, Lu K, Ding Y, Zhao Y, Chai Z: Lung deposition and extrapulmonary translocation of nano-ceria after intratracheal instillation. Nanotechnology 2010;21:285103.

12 Nemmar A, Al-Salam S, Beegam S, Yuvaraju P, Ali BH: The acute pulmonary and thrombotic effects of cerium oxide nanoparticles after intratracheal instillation in mice. Int J Nanomedicine 2017;12:2913-2922.

13 Nemmar A, Yuvaraju P, Beegam S, Fahim MA, Ali BH: Cerium Oxide Nanoparticles in Lung Acutely Induce Oxidative Stress, Inflammation, and DNA Damage in Various Organs of Mice. Oxid Med Cell Longev 2017;2017:9639035.

- 14 Domenech P, Perez T, Saldarini A, Uad P, Musso CG: Kidney-lung pathophysiological crosstalk: its characteristics and importance. Int Urol Nephrol 2017;49:1211-1215.

- 15 Xu X, Wang G, Chen N, Lu T, Nie S, Xu G, Zhang P, Luo Y, Wang Y, Wang X, Schwartz J, Geng J, Hou FF: LongTerm Exposure to Air Pollution and Increased Risk of Membranous Nephropathy in China. J Am Soc Nephrol 2016;27:3739-3746. 


\section{Cellular Physiology Cell Physiol Biochem 2019;52:439-454 \begin{tabular}{ll|l} 
DOI: 10.33594/000000032 & ( 2019 The Author(s). Published by \\
\hline and Biochemistry
\end{tabular} and Biochemistry Published online: 15 March 2019 Cell Physiol Biochem Press GmbH\&Co. KG \\ Nemmar et al.: Cerium Oxide Nanoparticles and Acute Kidney Injury}

- 16 Lue SH, Wellenius GA, Wilker EH, Mostofsky E, Mittleman MA: Residential proximity to major roadways and renal function. J Epidemiol Community Health 2013;67:629-634.

- 17 Nemmar A, Al Salam S, Zia S, Yasin J, Al H, I, Ali BH: Diesel exhaust particles in the lung aggravate experimental acute renal failure. Toxicol Sci 2010;113:267-277.

- 18 Nemmar A, Karaca T, Beegam S, Yuvaraju P, Yasin J, Hamadi NK, Ali BH: Prolonged Pulmonary Exposure to Diesel Exhaust Particles Exacerbates Renal Oxidative Stress, Inflammation and DNA Damage in Mice with Adenine-Induced Chronic Renal Failure. Cell Physiol Biochem 2016;38:1703-1713.

- 19 Manne ND, Arvapalli R, Nepal N, Shokuhfar T, Rice KM, Asano S, Blough ER: Cerium oxide nanoparticles attenuate acute kidney injury induced by intra-abdominal infection in Sprague-Dawley rats. J Nanobiotechnology 2015;13:75.

20 Ali BH, Al-Salam S, Al Husseini IS, Al-Lawati I, Waly M, Yasin J, Fahim M, Nemmar A: Abrogation of cisplatininduced nephrotoxicity by emodin in rats. Fundam Clin Pharmacol 2013;27:192-200.

21 Ma JY, Young SH, Mercer RR, Barger M, Schwegler-Berry D, Ma JK, Castranova V: Interactive effects of cerium oxide and diesel exhaust nanoparticles on inducing pulmonary fibrosis. Toxicol Appl Pharmacol 2014;278:135-147.

22 Ali BH, Al Moundhri MS, Tag EM, Nemmar A, Tanira MO: The ameliorative effect of cysteine prodrug L-2oxothiazolidine-4-carboxylic acid on cisplatin-induced nephrotoxicity in rats. Fundam Clin Pharmacol 2007;21:547-553.

- 23 Ali BH, Al Moundhri M, Eldin MT, Nemmar A, Al Siyabi S, Annamalai K: Amelioration of cisplatin-induced nephrotoxicity in rats by tetramethylpyrazine, a major constituent of the Chinese herb Ligusticum wallichi. Exp Biol Med (Maywood) 2008;233:891-896.

- 24 Zhao H, Qin HY, Cao LF, Chen YH, Tan ZX, Zhang C, Xu DX: Phenylbutyric acid inhibits epithelialmesenchymal transition during bleomycin-induced lung fibrosis. Toxicol Lett 2015;232:213-220.

25 Nemmar A, Al-Salam S, Yuvaraju P, Beegam S, Ali BH: Emodin mitigates diesel exhaust particles-induced increase in airway resistance, inflammation and oxidative stress in mice. Respir Physiol Neurobiol 2015;215:51-57.

26 Tsikas D: Methods of quantitative analysis of the nitric oxide metabolites nitrite and nitrate in human biological fluids. Free Radic Res 2005;39:797-815.

27 Wennmalm A, Benthin G, Edlund A, Jungersten L, Kieler-Jensen N, Lundin S, Westfelt UN, Petersson AS, Waagstein F: Metabolism and excretion of nitric oxide in humans. An experimental and clinical study. Circ Res 1993;73:1121-1127.

28 Al Suleimani YM, Al Mahruqi AS, Al ZM, Shalaby A, Ashique M, Nemmar A, Ali BH: Effect of diesel exhaust particles on renal vascular responses in rats with chronic kidney disease. Environ Toxicol 2017;32:541549.

- 29 Nemmar A, Yuvaraju P, Beegam S, Yasin J, Kazzam EE, Ali BH: Oxidative stress, inflammation, and DNA damage in multiple organs of mice acutely exposed to amorphous silica nanoparticles. Int J Nanomedicine 2016;11:919-928.

- 30 Nemmar A, Al-Salam S, Yuvaraju P, Beegam S, Yasin J, Ali BH: Chronic Exposure to Water-Pipe Smoke Induces Alveolar Enlargement, DNA Damage and Impairment of Lung Function. Cell Physiol Biochem 2016;38:982-992.

- 31 Nemmar A, Beegam S, Yuvaraju P, Yasin J, Tariq S, Attoub S, Ali BH: Ultrasmall superparamagnetic iron oxide nanoparticles acutely promote thrombosis and cardiac oxidative stress and DNA damage in mice. Part Fibre Toxicol 2016;13:22.

- 32 Olive PL, Banath JP, Fjell CD: DNA strand breakage and DNA structure influence staining with propidium iodide using the alkaline comet assay. Cytometry 1994;16:305-312.

33 Hartmann A, Speit G: The contribution of cytotoxicity to DNA-effects in the single cell gel test (comet assay). Toxicol Lett 1997;90:183-188.

34 Yao X, Panichpisal K, Kurtzman N, Nugent K: Cisplatin nephrotoxicity: a review. Am J Med Sci 2007;334:115-124.

- 35 Chirino YI, Pedraza-Chaverri J: Role of oxidative and nitrosative stress in cisplatin-induced nephrotoxicity. Exp Toxicol Pathol 2009;61:223-242.

- 36 Mohan IK, Khan M, Shobha JC, Naidu MU, Prayag A, Kuppusamy P, Kutala VK: Protection against cisplatininduced nephrotoxicity by Spirulina in rats. Cancer Chemother Pharmacol 2006;58:802-808. 


\section{Cellular Physiology Cell Physiol Biochem 2019;52:439-454

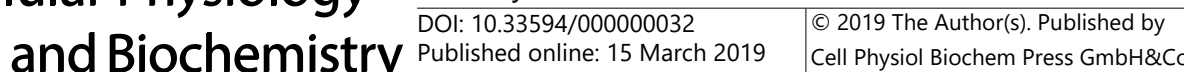 \\ Nemmar et al.: Cerium Oxide Nanoparticles and Acute Kidney Injury}

37 Wingard CJ, Walters DM, Cathey BL, Hilderbrand SC, Katwa P, Lin S, Ke PC, Podila R, Rao A, Lust RM, Brown JM: Mast cells contribute to altered vascular reactivity and ischemia-reperfusion injury following cerium oxide nanoparticle instillation. Nanotoxicology 2011;5:531-545.

38 Driscoll KE, Costa DL, Hatch G, Henderson R, Oberdorster G, Salem H, Schlesinger RB: Intratracheal instillation as an exposure technique for the evaluation of respiratory tract toxicity: uses and limitations. Toxicol Sci 2000;55:24-35.

39 Niu J, Wang K, Kolattukudy PE: Cerium oxide nanoparticles inhibit oxidative stress and nuclear factorkappaB activation in H9c2 cardiomyocytes exposed to cigarette smoke extract. J Pharmacol Exp Ther 2011;338:53-61.

40 Miller MR, Raftis JB, Langrish JP, McLean SG, Samutrtai P, Connell SP, Wilson S, Vesey AT, Fokkens PHB, Boere AJF, Krystek P, Campbell CJ, Hadoke PWF, Donaldson K, Cassee FR, Newby DE, Duffin R, Mills NL: Inhaled Nanoparticles Accumulate at Sites of Vascular Disease. ACS Nano 2017;11:4542-4552.

41 Nemmar A, Hoet PH, Vanquickenborne B, Dinsdale D, Thomeer M, Hoylaerts MF, Vanbilloen H, Mortelmans L, Nemery B: Passage of inhaled particles into the blood circulation in humans. Circulation 2002;105:411414.

42 Pery AR, Brochot C, Hoet PH, Nemmar A, Bois FY: Development of a physiologically based kinetic model for 99m-Technetium-labelled carbon nanoparticles inhaled by humans. Inhal Toxicol 2009;21:1099-1107.

43 Xu X, Nie S, Ding H, Hou FF: Environmental pollution and kidney diseases. Nat Rev Nephrol 2018;14:313324.

- 44 Waring WS, Moonie A: Earlier recognition of nephrotoxicity using novel biomarkers of acute kidney injury. Clin Toxicol (Phila) 2011;49:720-728.

- 45 Al-Kharusi N, Babiker HA, Al-Salam S, Waly MI, Nemmar A, Al-Lawati I, Yasin J, Beegam S, Ali BH: Ellagic acid protects against cisplatin-induced nephrotoxicity in rats: a dose-dependent study. Eur Rev Med Pharmacol Sci 2013;17:299-310.

46 Saber AT, Bornholdt J, Dybdahl M, Sharma AK, Loft S, Vogel U, Wallin H: Tumor necrosis factor is not required for particle-induced genotoxicity and pulmonary inflammation. Arch Toxicol 2005;79:177-182.

47 Radomska A, Leszczyszyn J, Radomski MW: The Nanopharmacology and Nanotoxicology of Nanomaterials: New Opportunities and Challenges. Adv Clin Exp Med 2016;25:151-162.

48 Nemmar A, Holme JA, Rosas I, Schwarze PE, Alfaro-Moreno E: Recent advances in particulate matter and nanoparticle toxicology: a review of the in vivo and in vitro studies. Biomed Res Int 2013;2013:279371.

49 Visconti L, Santoro D, Cernaro V, Buemi M, Lacquaniti A: Kidney-lung connections in acute and chronic diseases: current perspectives. J Nephrol 2016;29:341-348.

- 50 Forstermann U: Nitric oxide and oxidative stress in vascular disease. Pflugers Arch 2010;459:923-939.

- 51 Nemmar A, Karaca T, Beegam S, Yuvaraju P, Yasin J, Ali BH: Lung Oxidative Stress, DNA Damage, Apoptosis, and Fibrosis in Adenine-Induced Chronic Kidney Disease in Mice. Front Physiol 2017;8:896. 